\title{
Growth control of Listeria innocua 2030c on vacuum-packaged cold-smoked salmon by lactic acid bacteria
}

\author{
Elisabetta Tomé ${ }^{\mathrm{a}, \mathrm{b}}$, Paul A. Gibbs ${ }^{\mathrm{a}, \mathrm{c}}$, Paula C. Teixeira ${ }^{\mathrm{a}, *}$ \\ ${ }^{a}$ Escola Superior de Biotecnologia, Universidade Católica Portuguesa, R. Dr. António Bernardino de Almeida, 4200-072 Porto, Portugal \\ ${ }^{\mathrm{b}}$ Instituto de Ciencias y Tecnología de Alimentos, Escuela de Biología, Universidad Central de Venezuela, Apartado 47.097 - Caracas 1041 A, Venezuela \\ ${ }^{\mathrm{c}}$ Leatherhead Food International, Surrey, UK
}

Keywords: Cold-smoked salmon; Lactic acid bacteria; Bacteriocins; Listeria; Biopreservation

\begin{abstract}
Five bacteriocin-producing lactic acid bacteria (LAB): Enterococcus faecium ET05, Lactobacillus curvatus ET06, L. curvatus ET30, L. deldrueckii ET32 and Pediococcus acidilactici ET34, selected by their capacity for growth and producing inhibition in vitro at high salt-on-water content, low temperature and anaerobic atmosphere, conditions simulating cold-smoked fish, were inoculated onto salmon fillets, in co-culture with Listeria innocua $2030 \mathrm{c}$, and cold-smoked processed (dry salted for $6 \mathrm{~h}$; drying for $6 \mathrm{~h}$; smoke for $2 \mathrm{~h}$ ). The finished product was then packed under vacuum and stored at $5{ }^{\circ} \mathrm{C}$. Enumeration of LAB and L. innocua was performed during storage. Results showed that strain E. faecium ET05 was the best biopreservative candidate for controlling L. innocua growth in vacuum-packaged cold-smoked salmon (CSS) processed under the salting/drying/smoking parameters referred above. L. curvatus ET30 and L. delbrueckii ET32 also showed a good biopreservation potential for CSS although they were less effective than the former. L. curvatus ET06 and P. acidilactici ET34 showed a bacteriostatic mode of action against the target bacteria in vitro as well as when inoculated into the salmon fillets.
\end{abstract}

This study describes a potential application of five different LAB in the biopreservation of Listeria in CSS.

\section{Introduction}

Cold-smoked salmon (CSS) is a typical seafood product subjected to only a light preservation process before being purchased 'ready-to-eat' by the consumer. As a result, the human pathogen Listeria monocytogenes, is often isolated from this product, albeit in low numbers (Jinneman et al., 1999; Johansson et al., 1999). L. monocytogenes is the causative agent of listeriosis with $30 \%$ lethality rate in compromised individuals (Duffes et al., 1999). None of the preservation parameters, individually or combined, used in the manufacture of CSS, can control the presence or growth of this bacterium, which has been described as a ubiquitous microorganism capable of growth at

\footnotetext{
* Corresponding author. Tel.: +35122 5580001; fax: +351 225090351 . E-mail address: paula@esb.ucp.pt (P.C. Teixeira).
}

$\mathrm{pH}$ values as low as 5, at refrigeration temperature, and at very high salt concentrations (Eklund et al., 1995).

Although many technologies have been applied successfully in CSS to prevent growth of L. monocytogenes, i.e. the addition of low concentration of lactic acid and/or acetic acid, potassium lactate and sodium diacetate (Yoon et al., 2004; Vogel et al., 2006), there is a growing demand by consumers for lightly preserved fish products (and other foods) that do not contain chemical preservatives but still have a long and safe shelf life. Interest in developing biopreservation techniques in lightly preserved foods has increased in recent decades and has focused on minimizing the presence of and/or suppressing the growth of L. monocytogenes. Biopreservation is the extension of the storage life and enhancing the safety of foods using the natural or controlled microflora and/or their antimicrobial products (Stiles, 1996). In CSS biopreservation techniques have involved the introduction of a competitive LAB microflora for their protective 
effects, including bacteriocin-producing $\mathrm{LAB}$, and purified antilisterial bacteriocins (Hugas and Monfort, 1997). The advantages of protective cultures include additive-free preservation, natural image, and temperature-responsive inhibition - it can "switch on" only when temperature abuse takes place (Devlieghere et al., 2004). The addition of protective cultures directly into the product offers a controlled process in terms of desired safety outcomes and in the prevention of uncontrollable spoilage. Furthermore, the constant production of bacteriocin by viable cultures can overcome the problem of their decomposition and binding to food particles when used as an additive (Rodgers, 2001). Potential but very rare health risks associated with LAB include bacteremia, associated with vancomycin therapy (Stiles, 1996). Evidence of non-pathogenicity, such as being non-haemolytic and antibiotic sensitive (Embarek et al., 1994), should be demonstrated for cultures to be used as protective cultures in foods, especially in the case of antilisterial Enterococcus and Bacillus species in which the horizontal transfer of plasmids may dramatically alter their phenotypes in terms of their pathogenicity (Helgason et al., 2000).

Many studies have demonstrated that LAB comprises the dominant microflora in CSS (González-Rodríguez et al., 2002; Cardinal et al., 2004). Most of them are able to hamper the growth of $L$. monocytogenes due to the production of diverse compounds including antimicrobials produced at high cell density, or peptides called bacteriocins (Lindgren and Dobrogosz, 1990; Kleerebezem, 2004). There is strong evidence for their use as potential bioprotective cultures for CSS. However, the use of protective cultures in CSS has focused on the genus Carnobacterium (Nilsson et al., 1999; Nilsson et al., 2004; Duffes et al., 1999, 1999a; Connil et al., 2002; Yamazaki et al., 2003; Brillet et al., 2004; Vaz-Velho et al., 2005; Vescovo et al., 2006) and to a lesser extent on L. sakei (Katla et al., 2001), L. curvatus (Ghalfi et al., 2006), L. casei and L. plantarum (Vescovo et al., 2006). In this study, the ability of five strains isolated from CSS, identified as E. faecium ET05, L. curvatus ET06 and ET30, L. delbrueckii ET32 and P. acidilactici ET34 (capable of growth and producing listerial inhibition in vitro, under conditions prevailing in vacuum-packaged CSS fillets; sensitivity to vancomycin, unable to produce histamine and lacking haemolytic activity by E. faecium ET05 strain, (Tomé et al., 2007) to inhibit the growth of L. monocytogenes during CSS production was investigated. In parallel with the biopreservation study, the mode of action of the bacteriocins produced by the strains inoculated into the fillets, was assessed using in vitro assays.

\section{Materials and methods}

Efficacy of protective lactic acid bacteria in growth control of L. innocua $2030 \mathrm{c}$ on cold-smoked salmon

\section{Raw fish}

Fresh gutted farmed salmon (Salmo salar) from Norway were acquired at Matosinhos' Doca (Porto, Portugal). Salmon arrived by lorry ( $72 \mathrm{~h}$ travel) in a chilled container with the temperature controlled between $0{ }^{\circ} \mathrm{C}$ and $4{ }^{\circ} \mathrm{C}$, inside poly- styrene boxes (two layers of fish between two layers of ice). The fish was transported to the Escola Superior de Biotecnologia (Porto, Portugal) in chilled conditions, beheaded and filleted by hand on the same day.

\section{Pure cultures}

Five inhibitory LAB previously isolated from CSS, and capable of growth and producing inhibition in vitro at high osmolarity, low temperature and anaerobic atmosphere, conditions simulating cold-smoked fish, were selected for inoculation onto salmon fillets. Two overnight subcultures of $E$. faecium ET05, L. delbrueckii ET32 and P. acidilactici ET34 incubated for $30 \mathrm{~h}$ (yielding $10^{8-10} \mathrm{cfu} \mathrm{ml}^{-1}$ ) and for L. curvatus ET06 and ET30 incubated for $48 \mathrm{~h}$ (yielding $10^{11-12} \mathrm{cfu} \mathrm{ml}^{-1}$ and $10^{9-10} \mathrm{cfu} \mathrm{ml}^{-1}$, respectively) were made in APT broth at $30{ }^{\circ} \mathrm{C}$ before experimental use. L. innocua $2030 \mathrm{c}$, a tetracycline resistant strain from Public Health Laboratory Services (PHLS, London) private collection, was used as target organism. Two overnight subcultures $\left(30^{\circ} \mathrm{C}, 18 \mathrm{~h}\right.$ yielding $\left.10^{8-9} \mathrm{cfu} \mathrm{ml}^{-1}\right)$ of L. innocua 2030c previously stored on Lab Lemco agar (Oxoid, Hampshire, UK) at ambient temperature, were made in TSB-YE (Lab M, Bury, UK) before experimental use. The selection of L. innocua $2030 \mathrm{c}$ as an alternative organism to L. monocytogenes, was due to the restriction on the use of this pathogen in the processing plant; this strain had previously been selected as a suitable marker organism for replacing $L$. monocytogenes in experiments where antilisterial properties of LAB strains were evaluated (Vaz-Velho et al., 2001).

\section{Treatments}

Overnight cultures $(20 \mathrm{ml})$ of L. innocua 2030c and of LAB strains ET05, ET06, ET30, ET32, ET34 were centrifuged at $8670 \times g$, for $10 \mathrm{~min}$ at $4{ }^{\circ} \mathrm{C}$ (Hettich, Rotina $35 \mathrm{R}$, Tuttlingen, Germany). Each pellet was re-suspended in $20 \mathrm{ml}$ of sterile saline solution $(1 \% \mathrm{w} / \mathrm{v} \mathrm{NaCl}$ in water) and each cell suspension was diluted in $11(2 \% \mathrm{v} / \mathrm{v})$ of water. Two fish fillets were immersed for $30 \mathrm{~s}$ in this volume as required by trials $1-4$. Trials are described in Table 1. Five independent experiments were performed with each lactic acid bacterium (see Table 2) described previously, and two independent runs (batches) were performed in each experiment at the same time of the year. Salmon fillets were dry salted for $6 \mathrm{~h}$ (salt: fish::1:3) at $5{ }^{\circ} \mathrm{C}$. Sugar was added to the salt in the proportion 1:3::sugar:salt. The total weight of salt and sugar corresponded to one third of the weight of the fillet. After salting, the fillets were washed/rubbed to remove the surplus salt and were drained/dried overnight at $5{ }^{\circ} \mathrm{C}$. Then fish fillets were placed inside the smoking kiln for $6 \mathrm{~h}$ of drying and $2 \mathrm{~h}$ of exposure to smoke at $<30^{\circ} \mathrm{C}$. The smoked samples were cooled overnight at $5{ }^{\circ} \mathrm{C}$. The following

Table 1

Design of the trials used in the inoculation of the salmon fillets

\begin{tabular}{lll}
\hline Trial & L. innocua 2030c & LAB culture \\
\hline 1 & No & No \\
2 & No & Yes \\
3 & Yes & Yes \\
4 & Yes & No \\
\hline
\end{tabular}


Table 2

Lactic acid bacterium used as inoculum in trials 2 and 3 in each experiment

\begin{tabular}{ll}
\hline Experiment & LAB inoculated \\
\hline 1 & E. faecium ET05 \\
2 & L. curvatus ET06 \\
3 & L. curvatus ET30 \\
4 & L. delbrueckii ET32 \\
5 & P. acidilactici ET34 \\
\hline
\end{tabular}

day, lug and pin bones and belly flaps were removed, the fillets sliced and vacuum-packed. Packs were stored for 3 weeks at $5{ }^{\circ} \mathrm{C}$ and sampled weekly.

\section{Sampling procedure}

Two salmon fillets from each trial were sampled to determine LAB and Listeria populations. Ten grams of each fillet (fresh or smoked material), taken from the centre of each fillet, were homogenized in $90 \mathrm{ml}$ of sterile BPW (Merck, Darmstadt, Germany) for 2 min in a Stomacher 400 Lab Blender (Seward Medical, London, UK). Serial dilutions in sterile 1/4 strength Ringer's solution (Lab M) were prepared. Enumeration of L. innocua 2030c and LAB was done on the raw material, after smoking, and weekly during the 3 weeks of storage at $5^{\circ} \mathrm{C}$. All samples in each trial were analysed in duplicate. Bacteriocin activity was measured in trial 2-samples from the homogenised (stomacher) filtered liquid after seven days of refrigerated storage. The samples were spotted onto indicator plates inoculated with L. monocytogenes 54 (ESB/UCP culture collection, Porto, Portugal). In a parallel study the bacteriocin activity adsorbed on plastic bags was tested by placing pieces of packaging material on indicator plates and incubated overnight at $25^{\circ} \mathrm{C}$.

\section{Physical and chemical analyses}

Salt concentration in the finished products was evaluated according to AOAC (1995), method 937.09 in samples taken from the negative control (trial 1) for two batches, in each experiment. The salt content was expressed as $\% \mathrm{NaCl}$ in water phase of muscle (Tomé et al., 1999). Moisture content of the samples of CSS was determined according AOAC (1995), method 24.003. These analyses were performed at the beginning of storage.

\section{Microbiological analyses}

LAB were enumerated by pour-plating in APT (Difco, Detroit, USA) agar. All colonies were counted as presumptive $\mathrm{LAB}$ after $5 \mathrm{~d}$ of anaerobic incubation at $25^{\circ} \mathrm{C}$. Listeria counts were obtained by direct plating suitable dilutions of product on Agar Listeria Ottavani \& Agosti (ALOA, bioMérieux, Marcy l'Etoile, France) medium. All blue-colored colonies without a halo around them were counted as presumptive Listeria spp. after $24-48 \mathrm{~h}$ of incubation at $37^{\circ} \mathrm{C}$.

\section{Statistical analysis}

ANOVA two-factors with replications and Multiple Range Test were used to evaluate differences of means between batches and treatments as well as the effect of the different treatments on L. innocua 2030c growth. The null hypothesis assumed that there was no difference between batches and between treated/untreated samples. Significant differences were considered when $P<0.05$. Analysis of variance and effects calculations were performed using Statistica 6.0 (StatSoft Inc., Oklahoma, USA).

\section{Bacteriocin activity}

Bacteriocin activity was measured in trial 2-samples from the homogenized stomacher filtered liquid after seven days of refrigerated storage. The samples were spotted onto plates inoculated with L. monocytogenes 54 (ESB/UCP). In parallel, activity adsorbed on plastic bags was tested by loading pieces of packaging material on indicator plates and incubated overnight at $25^{\circ} \mathrm{C}$.

\section{Mode of action}

The mode of action of the bacteriocins produced by strains ET05, ET06, ET30, ET32 and ET34, was studied in vitro. It was assessed by adding $20 \mathrm{ml}$ aliquots of each bacteriocincontaining filter-sterilized and cell-free supernatant (CFSF; $\mathrm{pH} 6.0$ ) to a $100 \mathrm{ml}$ culture of L. innocua $2030 \mathrm{c}$, at the onset of growth (at $37^{\circ} \mathrm{C}$ ) and again after $3 \mathrm{~h}$ and $5 \mathrm{~h}$ of growth. The
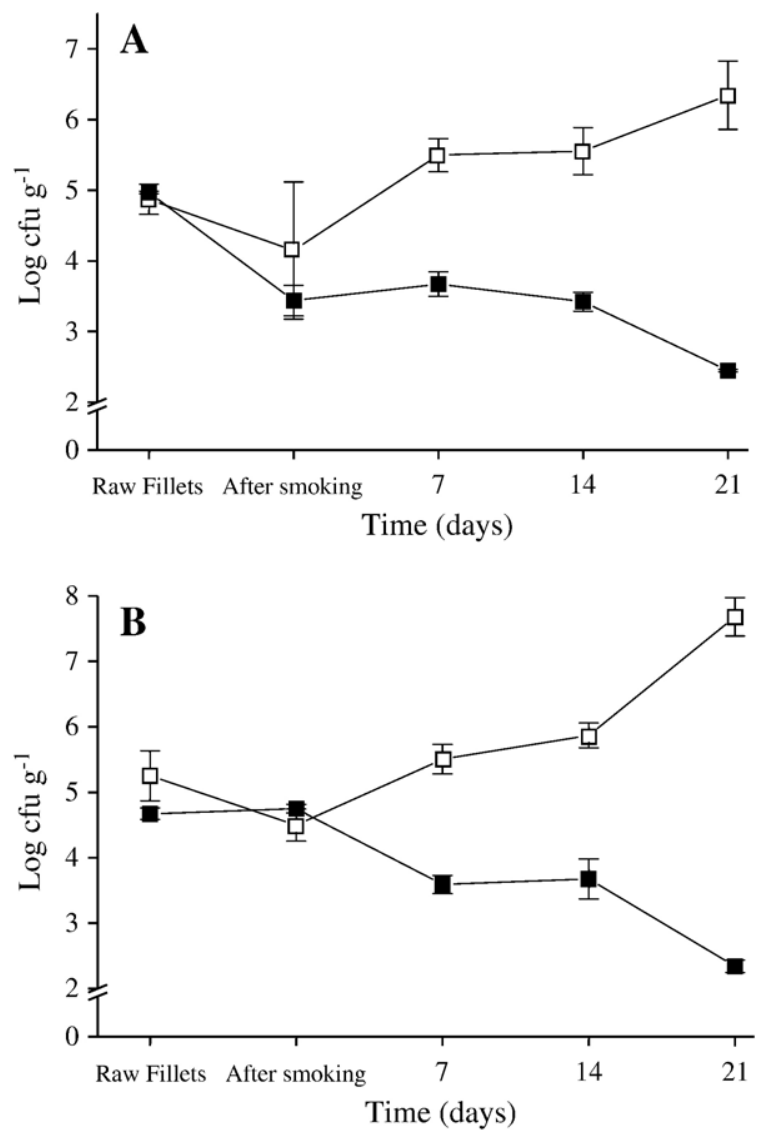

Fig. 1. Effect of E. faecium ET05 on L. innocua 2030c on salmon fillets before and after cold-smoking and during storage at $5{ }^{\circ} \mathrm{C}$ in vacuum packs for 21 days A) Batch 1, (B) Batch $2 \square$ L. innocua 2030c $\square$ L. innocua 2030c in a co-culture with E. faecium ET05. 
optical density $(600 \mathrm{~nm})$ of the culture was determined at regular intervals. Three independent experiments were run in duplicate.

Results

Efficacy of protective lactic acid bacteria on growth control of L. innocua 2030c on cold-smoked salmon

The potential of five antimicrobial-producing LAB strains to inhibit $L$. innocua 2030c growth, was evaluated in experiments comprising artificial contamination of salmon fillets, which were then smoked and stored in vacuum packs at $5{ }^{\circ} \mathrm{C}$ for 21 days. The two smoking batches performed for each inoculated strain, were treated separately for statistical analysis, since significant differences $(P<0.05)$ among batches were found in some of the assays, even though the smoking process for each batch was performed in the same month without great differences either in the temperature of the smoking process or in the relative humidity among batches in the same assay (results not shown).

A bactericidal-like effect on L. innocua 2030c was obtained in samples co-inoculated with E. faecium ET05 during the smoking stage (reduction of $\approx 1.5 \log$ cycles, batch 1 ) and, after
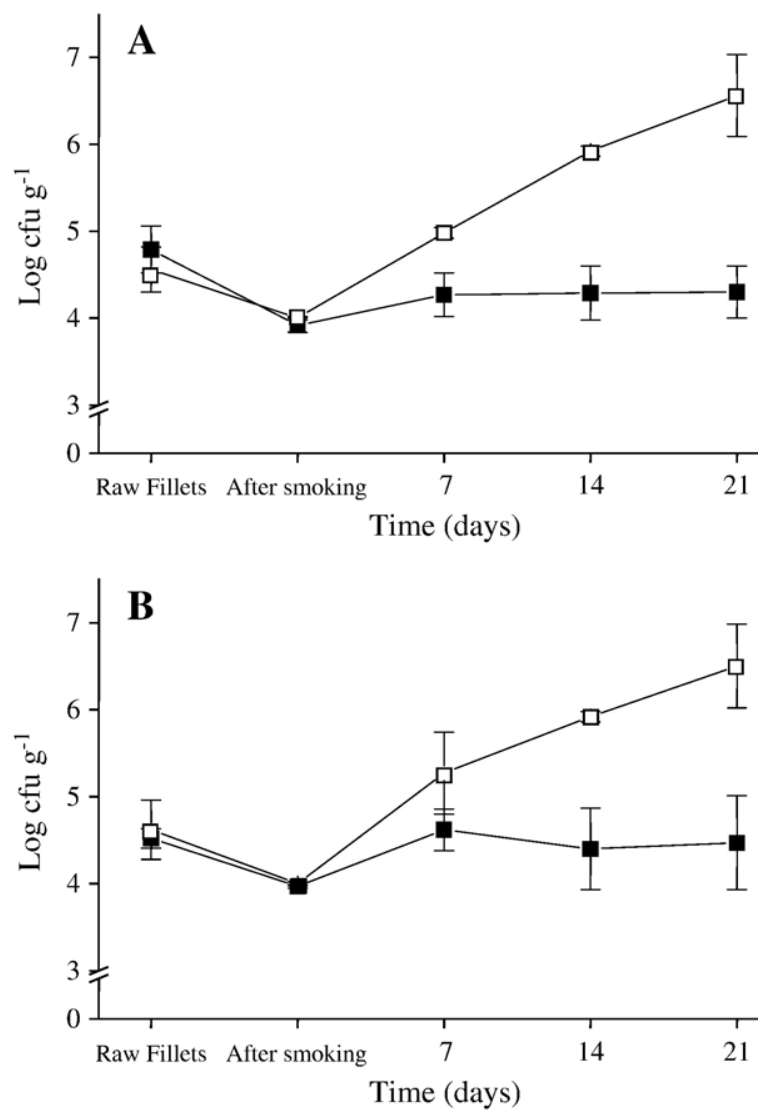

Fig. 2. Effect of L. curvatus ET06 on L. innocua 2030c on salmon fillets before and after cold-smoking processing and during storage at $5{ }^{\circ} \mathrm{C}$ in vacuum packs

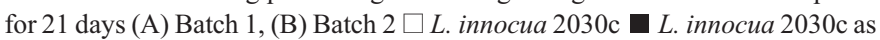
a co-culture with $L$. curvatus ET06.
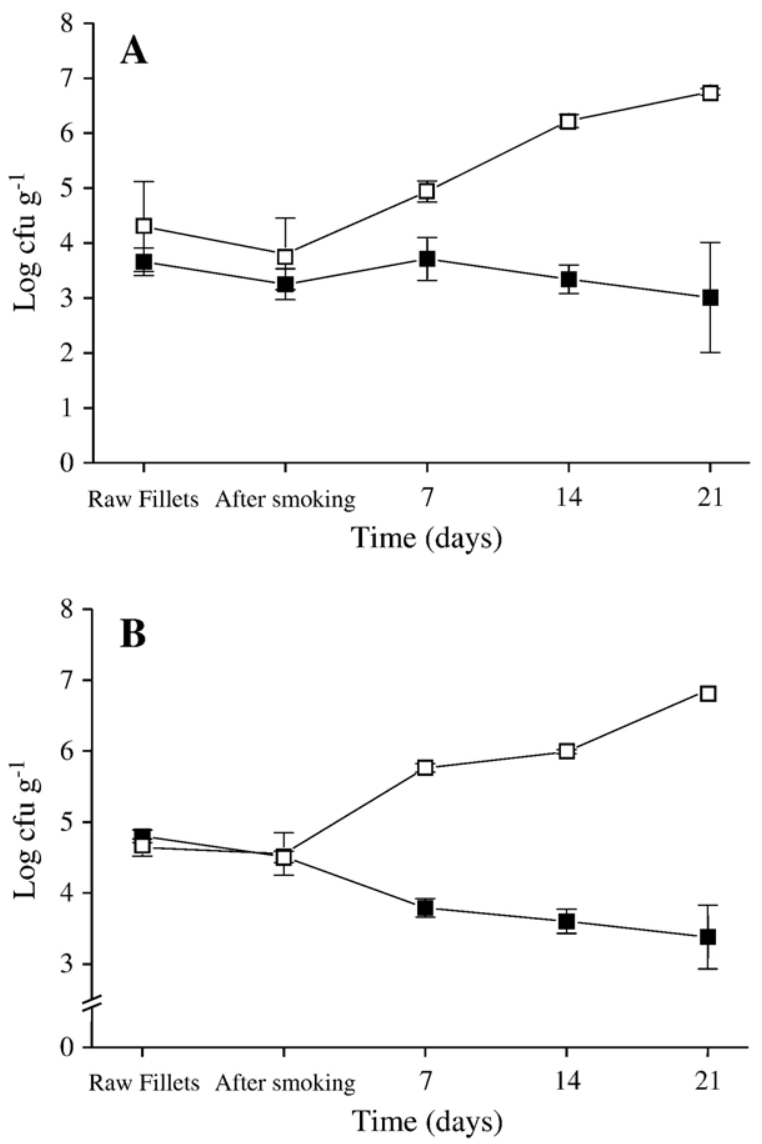

Fig. 3. Effect of L. curvatus ET30 on L. innocua 2030c on salmon fillets before and after cold-smoking processing and during storage at $5{ }^{\circ} \mathrm{C}$ in vacuum packs for 21 days (A) Batch 1, (B) Batch $2 \square$ L. innocua 2030c L. innocua 2030c as a co-culture with $L$. curvatus ET06.

seven days of storage (reduction of $\approx 1.25 \log$ cycles, batch 2 ) compared with the inoculum level. This effect was greater at the end of the storage period when counts of $L$. innocua were $\approx 2.5$ $\log$ cycles lower with respect to the raw inoculated fillets and $\approx 4.5 \log$ cycles lower than the control for both batches (Fig. 1). No significant differences $(P<0.05)$ were found in $L$. innocua counts in co-cultured samples among the batches.

Counts of L. innocua 2030c in samples treated with L. curvatus ET06 (Fig. 2) showed a slight recovery of $\approx 0.5 \log$ cycle from the beginning of storage (immediately after smoking) to the seventh day, compared to the control, and remained almost steady for the rest of the storage period. This treatment resulted in less than one log reduction of $L$. innocua numbers in batch 1 and no reduction in batch 2 at the end of the storage period, compared with the inoculum level. The L. curvatus ET06 culture showed a bacteriostatic-like effect on $L$. innocua growth. In batch 1 and batch 2 , statistical analysis considered this treatment to be significantly different $(P<0.05)$ from the control.

Samples treated with L. curvatus ET30 showed, in the first batch, a decrease in L. innocua 2030c numbers, compared with the control, from the 7th day of storage decreasing by ca. $2.3 \mathrm{log}$ cycles at the end of the storage period. There was no reduction of L. innocua 2030c counts obtained with respect to the initial inoculum level after 7 days (Fig. 3A). In the second batch, after 
smoking, a strong bactericidal effect on L. innocua 2030c compared to the inoculum level and to the control, was found in samples treated with L. curvatus ET30 culture. This reduction attained ca. $1.5 \log$ cycles and ca. $3.4 \log$ cycles in relation to the inoculum level and the control respectively, at the end of the storage period (Fig. 3B).

In the first batch, samples treated with L. delbrueckii ET32, showed during smoking, a reduction of ca. $1.3 \mathrm{log}$ cycles of L. innocua 2030c numbers below the inoculum level. However, numbers recovered after seven days of storage and remained steady below the inoculum level during further storage (Fig. 4A). In contrast, in the second batch, although counts of L. innocua 2030c remained close to the inoculum level until the seventh day of storage, a strong bactericidal-like effect was observed during the remaining period of storage. A reduction upper than $4 \log \mathrm{cfu}$ $\mathrm{g}^{-1}$ was achieved in these samples after 21 days of incubation compared with the control (Fig. 4B).

Results for the CSS fillets inoculated with $P$. acidilactici ET34 are illustrated in Fig. 5. In the non-LAB-inoculated assay (control) L. innocua $2030 \mathrm{c}$ reached $2.2 \times 10^{6} \mathrm{cfu}^{-1}$ and $3.4 \times 10^{7} \mathrm{cfu}^{-1}$, in batch 1 and batch 2 respectively, after 21 days of incubation in CSS vacuum-packaged at $5{ }^{\circ} \mathrm{C}$. The presence of $P$. acidilactici ET34 caused a reduction in L. innocua 2030c numbers, during smoking, of ca. 0.5 log cycle compared
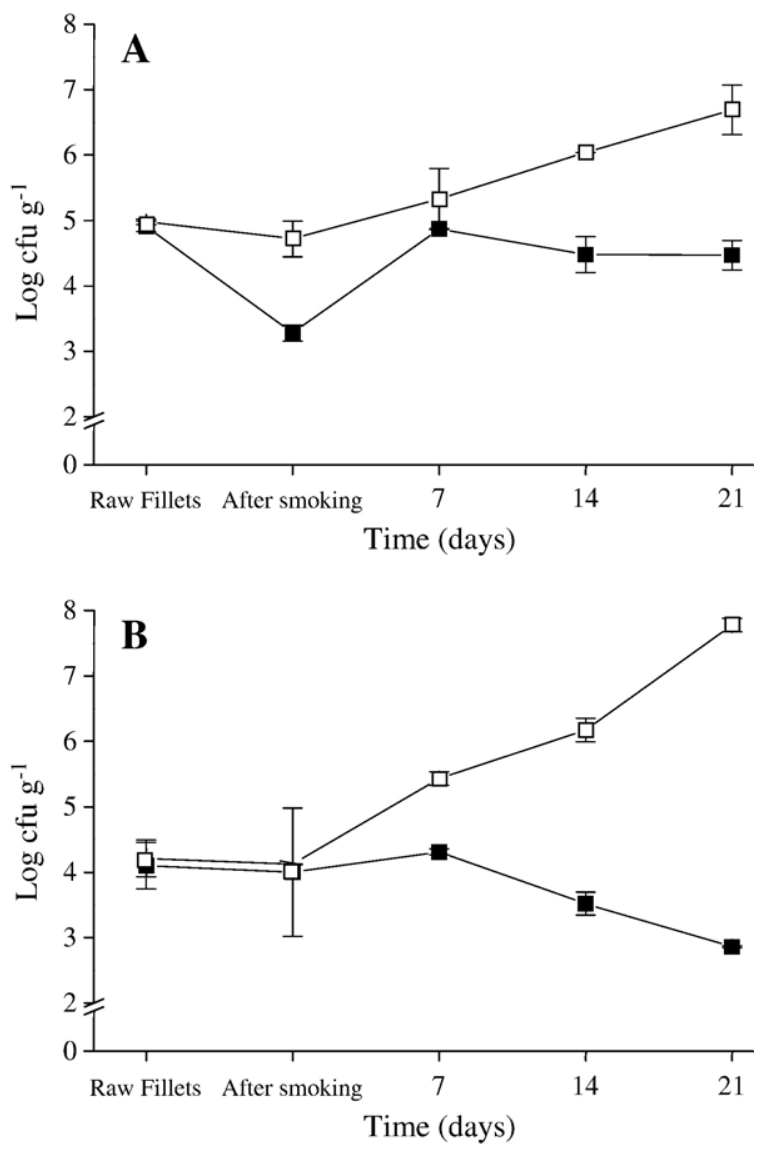

Fig. 4. Effect of L. delbrueckii ET32 on L. innocua 2030c on salmon fillets before and after cold-smoking and during storage at $5{ }^{\circ} \mathrm{C}$ in vacuum packs for 21 days A) Batch 1, (B) Batch $2 \square$ L. innocua 2030c $\square$ L. innocua 2030c in coculture with L. delbrueckii ET32.

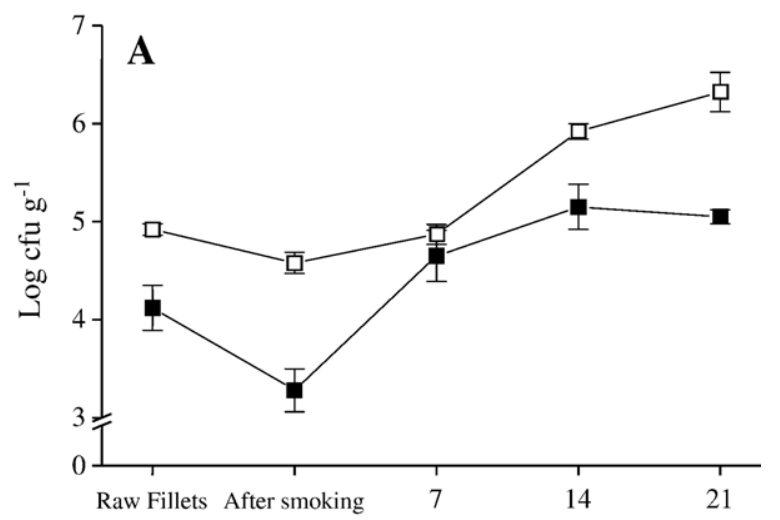

Time (days)

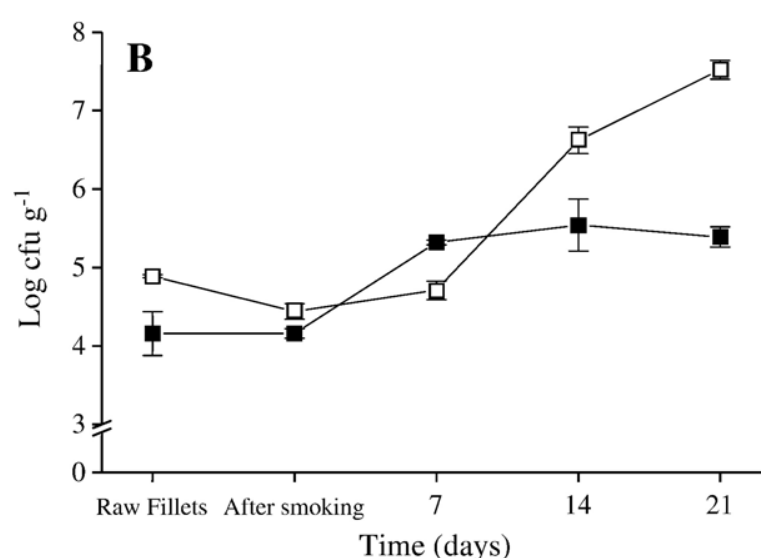

Fig. 5. Effect of $P$. acidilactici ET34 on L. innocua 2030c in salmon fillets before and after cold-smoking and during storage at $5{ }^{\circ} \mathrm{C}$ in vacuum packs for 21 days. (A) Batch 1, (B) Batch $2 \square$ L. innocua 2030c $\square$ L. innocua 2030c in co-culture with L. acidilactici ET34.

with the control in batch 1 , and no reduction in batch 2 . During storage, in the presence of the bacteriocinogenic culture, cell numbers of L. innocua 2030c increased, reaching a maximum of $10^{5} \mathrm{cfu} \mathrm{g}^{-1}$ after fourteen days of storage in both batches, and remained constant at that level during the rest of the incubation

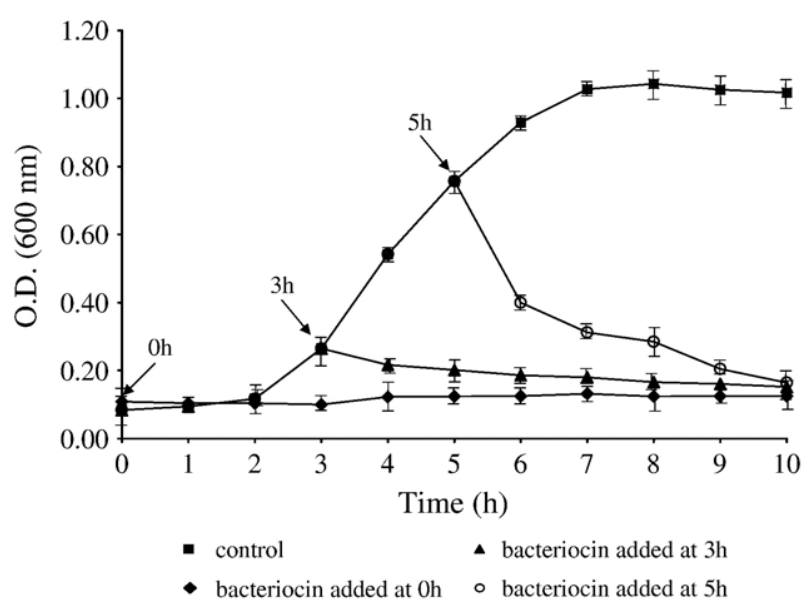

Fig. 6. Effect of bacteriocin ET05 addition on the growth of L. innocua 2030c. Data points represent the average of three experiments run in duplicate. 


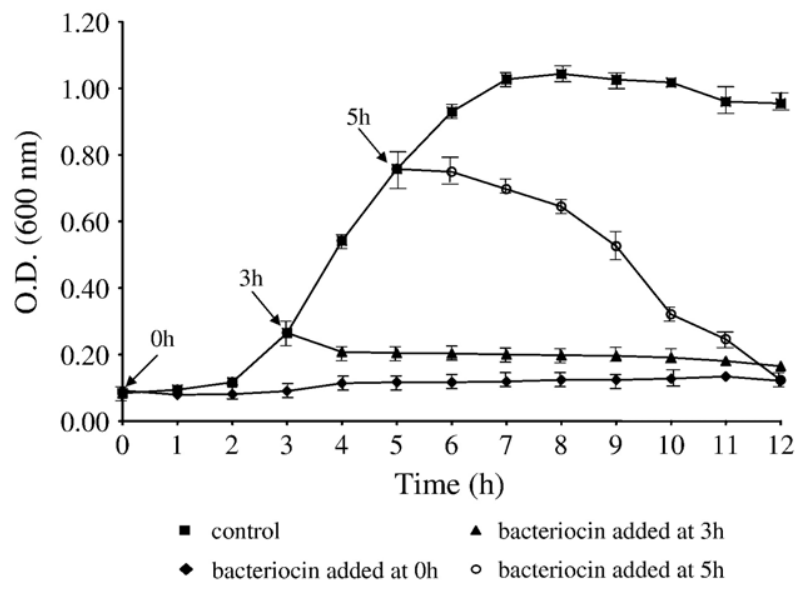

Fig. 7. Effect of bacteriocin ET06 addition on the growth of L. innocua 2030c. Data points represent the average of three experiments run in duplicate.

period. A weak bacteriostatic behavior seems to take place in these samples.

In general, an average initial cell concentration $10^{5-6} \mathrm{cfu} \mathrm{g}^{-1}$ of each of the LAB strains was obtained in each of the raw fillets of salmon inoculated independently, with E. faecium ET05, L. curvatus ET06, L. curvatus ET30, L. delbrueckii ET32 and $P$. acidilactici ET34, both in the first and the second batch (results not shown). The same pattern of increase in LAB numbers was observed both in inoculated and non-inoculated (L. innocua) samples, reaching $10^{9} \mathrm{cfu}^{-1}$ during the storage. There was no statistical difference $(P<0.05)$ in the count of $\mathrm{LAB}$ on CSS vacuum-packed fillets inoculated with each of the lactic acid strains ET05, ET06, ET30 and ET34 grown in coculture with L. innocua 2030c (trial 3 ) and the LAB count in the control (trial 2) in both batches. A significant difference was observed between trials 2 and 3 in CSS vacuum-packed fillets inoculated with L. delbrueckii ET32.

The residual activity of bacteriocins produced by the five strains inoculated into salmon fillets was not detected in any of the samples analysed after seven days of storage. Transfer of

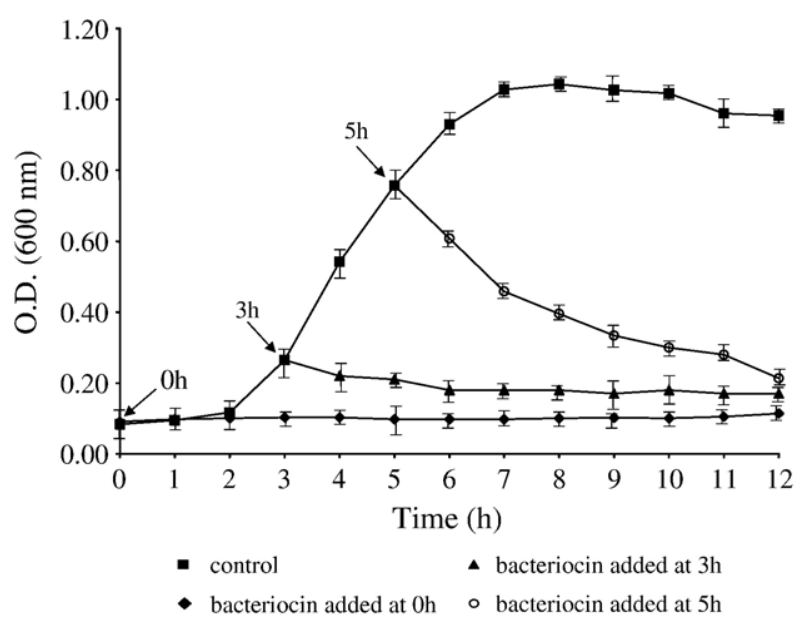

Fig. 8. Effect of bacteriocin ET30 addition on the growth of L. innocua 2030c. Data points represent the average of three experiments run in duplicate.

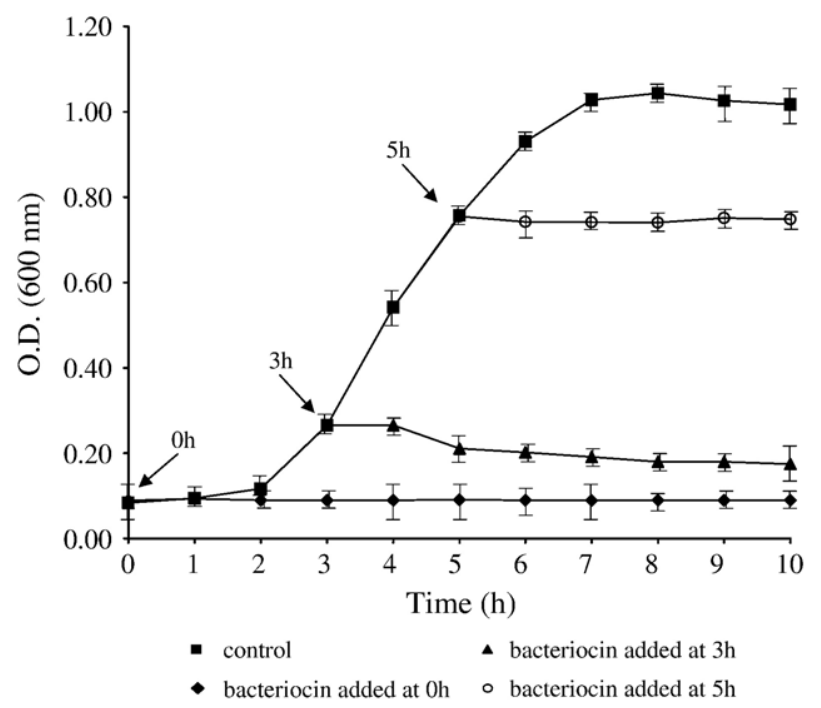

Fig. 9. Effect of bacteriocin ET32 addition on the growth of L. innocua 2030c. Data points represent the average of three experiments run in duplicate.

activity of bacteriocins ET05 and ET30 to the plastic package material was observed.

A slight variation among batches was noticed in the chemical composition. However there was no significant difference $(P<$ $0,05)$ in the percentage of salt in water phase between batches inoculated with the same LAB (results not shown). The percentage of salt in the water phase among all batches ranged between $3.3 \%$ and $4.8 \%$ with an average concentration of $3.9 \%$ $\mathrm{w} / \mathrm{v}$.

\section{Mode of action}

Addition of CFSF from E. faecium ET05 at the onset of growth $(0 \mathrm{~h})$ and again after $3 \mathrm{~h}$ and $5 \mathrm{~h}$ of growth to the cell suspension of $L$. innocua 2030c resulted in a very marked decrease in optical density (Fig. 6). The same effect was observed after the addition of CFSFs from $L$. curvatus ET30 and L. delbrueckii ET32 (Figs. 7 and 8) The addition of bacteriocins

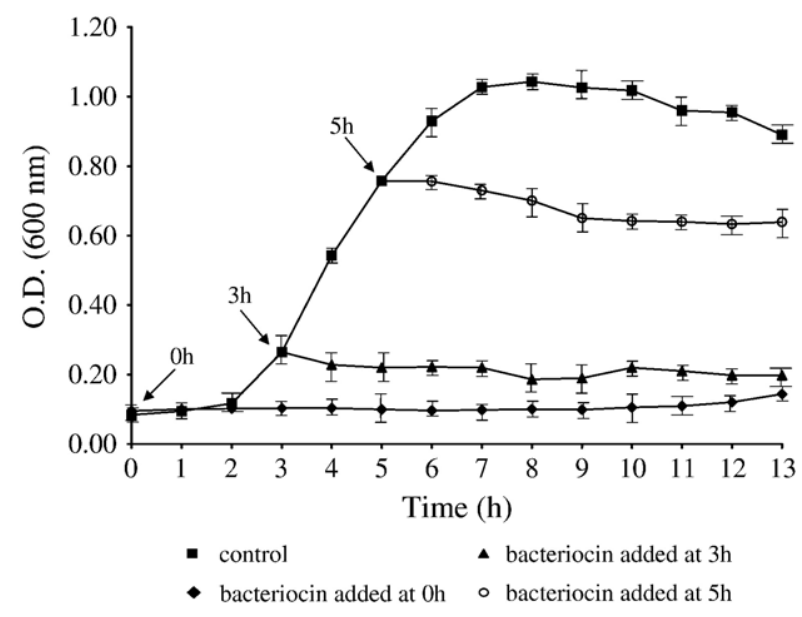

Fig. 10. Effect of bacteriocin ET34 addition on the growth of L. innocua 2030c. Data points represent the average of three experiments run in duplicate. 
ET06 and ET34 after $3 \mathrm{~h}$ and $5 \mathrm{~h}$ to a cell suspension of L. innосиа 2030c resulted in complete growth inhibition but no decrease in optical density (Figs. 9 and 10).

\section{Discussion}

Effect of protective lactic acid bacteria in growth control of L. innocua 2030c on cold-smoked salmon

The results of this study demonstrated a potential for application of five strains of LAB as biopreservative cultures against $L$. innocua 2030 c on vacuum-packaged CSS stored at $5{ }^{\circ} \mathrm{C}$. All the LAB strains suppressed the growth of the target microorganism. However, the highest reduction of L. innocua 2030c numbers at all sampling times was obtained with the E. faecium ET05 strain. It was demonstrated that $3.7 \% \mathrm{w} / \mathrm{w}$ of salt content (WPS) in fish fillets did not interfere with the growth of E. faecium ET05 in salmon fillets as well as bacteriocin production/activity, otherwise low levels of $L$. innocua 2030c would not be attained. On the other hand, neither the low temperature during the over-night storage before smoking, nor during the storage-time of CSS for 21 days at $5{ }^{\circ} \mathrm{C}$, would repress enterocin production. In contrast with our findings, Aymerich, Artigas, Garriga, Monfort and Hugas, (2000) reported that bacteriocin production of E. faecium CTC492 in dry-fermented sausages, was affected by low temperatures with an optimal production at temperatures between $25{ }^{\circ} \mathrm{C}$ and $35{ }^{\circ} \mathrm{C}$. The potential as antilisterial factors of enterococcal bacteriocins produced by E. faecium strains is well documented (Giraffa, 1995; Núñez et al., 1997; Foulquié Moreno et al., 2002). As result of their antimicrobial properties several E. faecium strains have already been proposed as starter culture or co-cultures in both dairy products and fermented foods (i.e. E. faecium T136, Casaus et al., 1997; E. faecium RZS C5, Leroy et al., 2003; Enterococcus casseliflavus IM 416K1, Sabia et al., 2002; E. faecium F58, Achemchem et al., 2005).

The results in this study have shown that $L$. curvatus ET06 had a bacteriostatic effect on L. innocua 2030c growth. In contrast, when $L$. curvatus ET30 culture was added to vacuumpackaged CSS, a bactericidal effect on $L$. innocua was observed. The inhibitory capacity of the bacteriocins produced by L. curvatus strains L442, LBPE and CWBI-B28 against L. monocytogenes were also observed by Mataragas, Drosinos and Metaxopoulos (2003), Benkerroum et al. (2005) and Ghalfi et al. (2006) in sliced, cooked, cured pork shoulder stored under vacuum at $4{ }^{\circ} \mathrm{C}$, dry-fermented sausage and CSS, respectively.

The main interest regarding $L$. delbrueckii comes from the importance of the subspecies bulgaricus and lactis due to their fermentation patterns and their tolerance and adaptive acid stress response. In addition, both subspecies are able to ferment lactose and to degrade casein and grow in milk. L. delbrueckii has also been used as a starter culture in meat fermentation processes. As a result of its homofermentative metabolism, the acid formed reduces the $\mathrm{pH}$, preventing the growth of food poisoning and spoilage bacteria. Kalalou, Faid and Ahami (2004) investigated the possibility of extending the shelf life of fresh camel meat using L. delbrueckii subsp. delbrueckii iso- lated from Moroccan foodstuffs, and selected for their inhibitory activity on Gram-positive and Gram-negative bacteria. Up to now, no data have been published on the preservation and extension of the shelf life of vacuum-packaged CSS by using L. delbrueckii and/or its metabolites. The addition of this LAB to salmon fillets in co-culture with $L$. innocua 2030 c could be considered successful. Even though batch 1 and 2 of salmon fillets treated with $L$. delbrueckii ET32 showed significant differences $(P<0.05)$ between them; when analysed separately, in each case statistical differences in L. innocua 2030c counts between treated and untreated samples were found during the storage period. As with E. faecium ET05, a considerable reduction in L. innocua 2030c numbers was observed with respect to the control samples, mainly in batch 2 . As a negative aspect we should comment that $L$. innocua counts only began to decrease on the seventh day of storage which could allow the pathogen growth up to this time.

Production of pediocins by pediococci has been intensively investigated in view of the potential use of either the purified bacteriocins or the producer cultures in biopreservation of foods. Pediocins produced by $P$. acidilactici or $P$. pentosaceus strains include pediocin AcH (Bhunia et al., 1988; Biswas et al., 1991), pediocin PA-1 (Gonzalez and Kunka, 1987; Pucci et al., 1988), pediocin JD (Christensen and Hutkins, 1992), pediocin SJ-1 (Schved et al., 1993), pediocin A (Piva and Headon, 1994), pediocin $\mathrm{PO}_{2}$ (Coventry et al., 1995), pediocin PD-1 (Green et al., 1997), pediocin Np5 (Manca de Nadra et al., 1998), and pediocin ACCEL (Wu et al., 2004).

The use of pediocin, mostly pediocin AcH (same as PA-1), mainly for biopreservation of meats, has been investigated in laboratory-scale, model studies. In studies with dry sausage fermentation, the use of bacteriocin-producing $P$. acidilactici JD1-23, P. acidilactici PAC 1.0 as fermenting agents, resulted in numbers of $L$. monocytogenes per gram of dry sausage that were 1-2 logs lower than those in control sausages (Berry et al., 1990; Foegeding et al., 1992; Luchansky et al., 1992; BaccusTaylor et al., 1993; Työppönen et al., 2003). Pediocin PA-1 was also experimentally used as a dried powder preparation to successfully inhibit $L$. monocytogenes in food systems such as dressed cottage cheese, half-and-half cream, and cheese sauce (Pucci et al., 1988). Two commercial antimicrobial compounds, Microgard (Rhône-Poulenc, Courbevoie, France) and Alta 2341 (Quest BioTechnology Inc., Sarasota, Fla., USA), have found use in the food industry and are licensed for use. These are not purified bacteriocin compounds but rather starter cultures of pediocin-producing bacteria that impart antibacterial properties to the foods (Stiles, 1996). However pediococci, compared to Lactobacillus and Pediococcus spp., are used relatively rarely as probiotics. In the current study the use of P. acidilactici ET34 in salmon fillets artificially contaminated with $L$. innocua $2030 \mathrm{c}$, prevented the growth of the indicator organism respect to the control. However a significant increase of the indicator pathogen was observed in LAB treated-samples during the first fourteen days of storage. In vitro assays showed that the bacteriocin ET34 produced by P. acidilactici ET34 has a bacteriostatic behavior towards L. innocua 2030c. It was also shown that this bacterium was tolerant of the stressful conditions 
existing in vacuum-packaged CSS since it was able to produce an active bacteriocin under these unfavorable conditions in broth culture (results not shown). However its behavior was slightly different when it was incorporated into the fish muscle; perhaps the bacteriocin activity was destroyed by proteolytic activities of the fish.

In none of the co-cultured samples with $\mathrm{LAB}$ was revival of L. innocua 2030c observed during the 21 days of storage. This could be a positive aspect indicating non-acquisition of resistance by L. innocua, at least over this short period of storage. The development of resistant mutants of Listeria spp. has been reported to occur for pediocin (Pucci et al., 1988), piscicolin (Ming and Daeschel, 1993; Wan et al., 1997) and carnocin (Mathieu et al., 1994). However, previously reported studies by Vaz-Velho et al. (2005) and Duffes et al. (1999) with L. innocua 2030c, as well as other L. monocytogenes strains, indicated that the main types of Portuguese L. monocytogenes strains in CSS as well as L. innocua 2030 c, were not associated with resistance to bacteriocins. On the other hand, the transference of bacteriocin activity to the plastic package material could be one of the reasons for non-detection of residual bacteriocin activity in the fish. According to Duffes et al. (1999) the attachment of the bacteriocins to packaging could be explained by the strongly hydrophobic properties of the molecules. Vaz-Velho et al. (2005) could not detect residual activity on samples of vacuumpackaged CSS previously treated with a $2 \% \mathrm{v} / \mathrm{v}$ suspension of a culture of $C$. divergens V41 analysed during 21 days of storage at $5{ }^{\circ} \mathrm{C}$. In several studies it has been shown that the inhibition of the target organism by bacteriocins is less effective in foods compared to laboratory media. Possible reasons may include: binding of bacteriocins to other organic compounds present in the food, including lipids, or plastic packaging (Henning et al., 1986; Jung et al., 1992), and inactivation of bacteriocins by proteases of food and of microbial origin (Schillinger et al., 1991). Larsen, Vogensen and Josephsen (1993) mentioned that the presence of moderate $\mathrm{NaCl}$ concentrations could lead to the inactivation or reduced production of bacteriocin. This last reason was not the case in the current study since at least the five strains inoculated into the fish fillets, were able to produce active bacteriocin using in vitro assays at salt concentrations up 5\% (Tomé et al., 2007). It seems most likely that the detection method used might not have been sufficiently sensitive to detect low levels of activity (1:10 dilution of fish) although any residual activity could have affected L. innocua growth. However, there was no evidence to indicate that the antilisterial effect of these five strains was due to anything other than bacteriocin activity, since in vitro experiments eliminated the possibility of other effective compounds - lactic acid, hydrogen peroxide (results not shown).

Concerning LAB counts, they were very homogeneous within the batches per treatment and intra-treatments (results not shown). No statistical differences between controls (Trials 1) and inoculated samples (Trials 2) were observed relative to LAB counts for strains ET05, ET06, ET30 and ET34. This means that in the presence of any of the inoculated LAB strains, the natural lactic acid flora grew as well as in the control, indicating that $\mathrm{LAB}$ are insensitive to the bacteriocin produced by each one of the bacteriocin-producing strains inoculated. Similar results were obtained by Brillet, Pilet, Prévost, Cardinal and Leroi (2005) when the inhibitory effect of $C$. divergens V41 against L. monocytogenes was assessed in CSS.

\section{Mode of action}

It is well known that the mode of inhibition of bacteriocins depends on the concentration, and on the nature and the physiological stage of the target strain. The bactericidal mode of action of bacteriocins on sensitive cells in most cases involves bacteriocin binding to cytoplasmic membranes, and formation of the poration complex (Abee 1995; Moll et al., 1999). This process finally leads to cell death that may occur with or without cell lysis, probably depending on concomitant activation of the cell autolysins. The enterocin of strain ET05 showed a bactericidal effect towards L. innocua 2030c (a rapid fall in OD). Similar results were achieved by Foulquié Moreno, Callewaert, Devreese, Van Beeumen and De Vuyst (2003) when the activity of six E. faecium strains isolated from different origins was compared.

A similar rapid bactericidal effect toward L. innocua 2030c was observed for bacteriocin of $L$. curvatus strain ET30, inducing cell lysis. An analogous pattern has been described for other bacteriocins produced by the genus Lactobacillus and Pediococcus, such as lactacin B produced by L. acidophilus (Barefoot and Klaenhammer, 1983), curvacin A from a strain of L. curvatus (Tichaczek et al., 1992), pediocin PA-1 from P. acidilactici and L. plantarum WHE 92 (Rodriguez et al., 2002). In contrast with the previous statement, the very similar viable cell counts of L. innocua 2030c at different time intervals (data not shown), suggest that the bacteriocin from L. curvatus ET06 strain, like pediocin produced by the isolate ET34 (Fig. 5), have a bacteriostatic action with respect to the indicator microorganism. It is not clear why a bacteriocin may act as a bacteriostat or as a bactericide, although Vescovo et al. (2006) investigating the potential growth of antimicrobial-producing LAB cultures in vacuum-packaged CSS, showed that $L$. casei was bacteriostatic against L. innocua when the former was inoculated at $6 \log \mathrm{cfu}$ $\mathrm{g}^{-1}$ but bactericidal at $8 \log \mathrm{cfu} \mathrm{g}^{-1}$. Similar findings were reported by Boris, Jiménez-Díaz, Caso and Barbés (2001) when partially-purified bacteriocin from $L$. delbrueckii was added to a sensitive Listeria strain; at high concentrations viable cell counts and optical density of the treated cultures decreased on continued incubation, indicating that it was bactericidal, whereas control cultures or samples treated with lower concentrations did not show a significant number of lysed cells.

In conclusion, this study has shown that particularly strains of E. faecium (ET05), L. curvatus (ET30) and L. delbrueckii (ET32) inoculated in CSS, exhibit some interesting properties that make them strong candidates for practical use as biopreservative adjunct cultures. However in vivo experiments must be designed to study what levels of these microorganisms are compatible with organoleptic qualities of CSS. Other positive features of these five LAB include their sensitivity to vancomycin and their lack of haemolytic activity $(\gamma$-haemolysis) by E. faecium strain ET05 (Tomé et al., 2007). 
This application will not replace other measures for controlling L. monocytogenes in CSS, but will act as an extra hurdle specifically designed to minimize the risk of listeriosis. Additionally, it is important to mention that in spite of bacteriocins ET06 from L. curvatus and bacteriocin ET34 from P. acidilactici having a bacteriostatic effect against $L$. innocua 2030c, the challenge level of Listeria used in the present study was very high (ca. $10^{5} \mathrm{cfu} \mathrm{g}^{-1}$ ) considering the actual level of Listeria encountered in vacuum-packaged CSS (in most cases less than 10 cells $\mathrm{g}^{-1}$ (Huss et al., 1998).

\section{Acknowledgement}

Financial support to author Tomé was provided by a $\mathrm{PhD}$ fellowship issued by Consejo de Desarrollo Científico y Humanístico de la Universidad Central de Venezuela.

\section{References}

Abee, T., 1995. Pore-forming bacteriocins of gram-positive bacteria and selfprotection mechanisms of producer organisms. FEMS Microbiology Letters $129,1-10$

Achemchem, F., Martínez-Bueno, M., Abrini, J., Valdivia, E., Maqueda, M., 2005. Enterococcus faecium F58, a bacteriocinogenic strain naturally occurring in Jben, a soft, farmhouse goat's cheese made in Morocco. Journal of Applied Microbiology 99, 141-150.

[AOAC] Official Methods of Analysis, 1995. Association of Official Analytical Chemists, 15th ed. Publ. AOAC International, 481 N. Frederick Avenue, Suite 500, Gaithersburg MD 20877-2417, USA.

Aymerich, T., Artigas, M.G., Garriga, M., Monfort, J.M., Hugas, M., 2000. Effect of sausage ingredients and additives on the production of enterocins A and B by Enterococcus faecium CTC492. Optimization of in vitro production and anti-listerial effect in dry fermented sausages. Journal of Applied Microbiology 88, 686-894.

Baccus-Taylor, G., Glass, K.A., Luchansky, J.B., Maurer, A.J., 1993. Fate of Listeria monocytogenes and pediococcal starter cultures during the manufacture of chicken summer sausage. Poultry Science 72, 1772-1778.

Barefoot, S.F., Klaenhammer, T.R., 1983. Detection and activity of lactacin B, a bacteriocin produced by Lactobacillus acidophilus. Applied and Environmental Microbiology 45 (6), 1808-1815.

Benkerroum, N., Daoudi, A., Hamraoui, T., Ghalfi, H., Thiry, C., Duroy, M., Evrart, P., Roblain, D., Thonart, P., 2005. Lyophilized preparations of bacteriocinogenic Lactobacillus curvatus and Lactococcus lactis subsp. lactis as potential protective adjuncts to control Listeria monocytogenes in dry-fermented sausages. Journal of Applied Microbiology 98 (1), 56-63.

Berry, E.D., Liewen, M.B., Mandigo, R.W., Hutkins, R.W., 1990. Inhibition of Listeria monocytogenes by bacteriocin producing Pediococcus during the manufacture of fermented semi-dry sausage. Journal of Food Protection 53, 194-199.

Bhunia, A.K., Johnson, M.C., Ray, B., 1988. Purification, characterization and antimicrobial spectrum of a bacteriocin produced by Pediococcus acidilactici. Journal of Applied Bacteriology 65, 4, 261-268.

Biswas, S.R., Ray, P., Johnson, M.C., Ray, B., 1991. Influence of growth conditions on the production of a bacteriocin, pediocin AcH, by Pediococcus acidilactici H. Applied and Environmental Microbiology 57, $1265-1267$.

Boris, S., Jiménez-Díaz, R., Caso, L.J., Barbés, C., 2001. Partial characterization of a bacteriocin produced by Lactobacillus delbrueckii subsp. lactis UO004, an intestinal isolate with probiotic potential. Journal of Applied Microbiology 91, 328-333.

Brillet, A., Pilet, M., Prévost, H., Bouttefroy, A., Leroi, F., 2004. Biodiversity of Listeria monocytogenes sensitivity to bacteriocin-producing Carnobacterium strains and application in sterile cold-smoked salmon. Journal of Applied Microbiology 97, 1029-1037.
Brillet, A., Pilet, M., Prévost, H., Cardinal, M., Leroi, F., 2005. Effect of inoculation of Carnobacterium divergens V41, a biopreservative strain against Listeria monocytogenes risk, on the microbiological, chemical and sensory quality of cold-smoked salmon. International Journal of Food Microbiology 104, 309-324.

Cardinal, M., Gunnlaugsdottir, H., Bjoernevik, M., Ouisse, A., Vallet, J.L., Leroi, F., 2004. Sensory characteristics of cold-smoked Atlantic salmon (Salmo salar) from European market and relationships with chemical, physical and microbiological measurements. Food Research International 37, 181-193.

Casaus, P., Nilsen, T., Cintas, L.M., Nes, I.F., Hernández, P., Holo, H., 1997. Enterocin B, a new bacteriocin from Enterococcus faecium T136 which can act synergistically with enterocin A. Microbiology 143, 2287-2294.

Christensen, D.P., Hutkins, R.W., 1992. Collapse of the proton motive force in Listeria monocytogenes caused by a bacteriocin produced by Pediococcus acidilactici. Applied and Environmental Microbiology 58, 10, 3312-3315.

Connil, N., Prévost, H., Dousset, X., 2002. Production of biogenic amines and divercin V41 in cold smoked salmon inoculated with Carnobacterium divergens $\mathrm{V} 41$, and specific detection of this strain by multiplex-PCR. Journal of Applied Microbiology 92, 611-617.

Coventry, M.J., Muirhead, K., Hickey, M.W., 1995. Partial characterisation of pediocin $\mathrm{PO}_{2}$ and comparison with nisin for biopreservation of meat products. International Journal of Food Microbiology 26, 133-145.

Devlieghere, F., Vermeiren, L., Debevere, J., 2004. New preservation technologies: possibilities and limitations. International Dairy Journal 14, 273-285.

Duffes, F., Corre, C., Leroi, F., Dousset, X., Boyaval, P., 1999. Inhibition of Listeria monocytogenes by in situ-produced and semipurified bacteriocins of Carnobacterium spp. on vacuum-packed cold-smoked salmon stored at $4{ }^{\circ} \mathrm{C}$ and $8{ }^{\circ} \mathrm{C}$. Journal of Food Protection 62 (12), 1394-1403.

Duffes, F., Leroi, F., Boyaval, P., Dousset, X., 1999a. Inhibition of Listeria monocytogenes by Carnobacterium spp. strains in a simulated cold-smoked fish system stored at $4{ }^{\circ} \mathrm{C}$. International Journal of Food Microbiology 47, $33-42$.

Eklund, M.W., Poysky, F.T., Paranjpye, R.N., Lashbrook, L.C., Peterson, M.E., Pelroy, G.A., 1995. Incidence and sources of Listeria monocytogenes in cold-smoked fishery products and processing plants. Journal of Food Protection 58 (5), 502-508.

Embarek, P.K., Jeppesen, V.F., Huss, H.H., 1994. Antibacterial potential of Enterococcus faecium strains to inhibit Clostridium botulinum in sous-vide cooked fish fillets. Food Microbiology 11, 525-536.

Foegeding, P.M., Thomas, A.B., Pilkington, D.H., Klaenhammer, T.R., 1992. Enhanced control of Listeria monocytogenes by in situ-produced pediocin during dry fermented sausage production. Applied and Environmental Microbiology $58,884-890$.

Foulquié Moreno, M.R., Callewaert, R., Devreese, B., Van Beeumen, J., De Vuyst, L., 2003. Isolation and biochemical characterisation of enterocins produced by enterococci from different sources. Journal of Applied Microbiology 94, 214-229.

Foulquié Moreno, M.R., Rea, M.C., Cogan, T.M., De Vuyst, L., 2002. Applicability of a bacteriocin-producing Enterococcus faecium as a co-culture in Cheddar cheese manufacture. International Journal of Food Microbiology 81, 73-84.

Ghalfi, H., Benkerroum, N., Thonart, P., Allaoui, A., Destain, J., 2006. Bacteriocin activity by Lactobacillus curvatus CWBI-B28 to inactivate Listeria monocytogenes in cold-smoked salmon during 4 degrees $\mathrm{C}$ storage. Journal of Food Protection 69 (5), 1066-1071.

Giraffa, G., 1995. Enterococcal bacteriocins: their potential as anti-Listeria factors in dairy technology. Food Microbiology 12, 291-299.

Gonzalez, C.F., Kunka, B.S., 1987. Plasmid-associated bacteriocin production and sucrose fermentation in Pediococcus acidilactici. Applied and Environmental Microbiology 53 (10), 2534-2538.

González-Rodríguez, M.N., Sanz, J.J., Santos, J.A., Otero, A., García-López, M.L., 2002. Numbers and types of microorganisms in vacuum-packed coldsmoked freshwater fish at the retail level. International Journal of Food Microbiology 77, 161-168.

Green, G., Dicks, L.M.T., Bruggeman, G., Vandamme, E.J., Chikindas, M.L., 1997. Pediocin PD-1, a bactericidal antimicrobial peptide from Pediococcus damnosus NCFB 1832. Journal of Applied Microbiology 83 (1), 127-132.

Helgason, E., Andreas, O., Caugant, A., Henning, A., Fouet, A., Mock, M., Hegna, I., Kolsto, A., 2000. Bacillus anthracis, Bacillus cereus and Bacillus 
thuringiensis - one species on the basis of genetic evidence. Applied and Environmental Microbiology 66, 2627-2630.

Henning, S., Metz, R., Hammes, W.P., 1986. Studies on the mode of action of nisin. International Journal of Food Microbiology 31, 121-134.

Hugas, M., Monfort, J.M., 1997. Bacterial starter cultures for meat fermentation. Food Chemistry 59 4, 547-554.

Huss, H.H., Nilsson, L., Jørgensen, L.V., 1998. Risk presented by Listeria monocytogenes on cold smoked salmon. Proccedings of Sixth International Symposium on Microbiology of Foods and Cosmetics in Europe. Enviromental Institute. Ispra, Italy, pp. 142-151.

Jinneman, K.C., Wekell, M.M., Eklund, M.W., 1999. Incidence and behaviour of Listeria monocytogenes in fish and seafood. In: Ryser, E.T., Marth, E.L.H. (Eds.), Listeria, listeriosis and food safety. Marcel Dekker, New York, pp. 601-630.

Johansson, T., Rantala, L., Palmu, L., Honkanen-Bulzalski, T., 1999. Occurrence and typing of Listeria monocytogenes strains in retail vacuum-packed fish products and in a production plant. International Journal of Food Microbiology 47, 111-119.

Jung, D.S., Bodyfelt, F.W., Daeschel, M.A., 1992. Influence of fat and emulsifiers on the efficacy of nisin in inhibiting Listeria monocytogenes in fluid milk. Journal of Dairy Science 75, 387-393.

Kalalou, I., Faid, M., Ahami, A.T., 2004. Extending shelf life of fresh minced camel meat at ambient temperature by Lactobacillus delbrueckii subsp. delbrueckii. Electronic Journal of Biotechnology 7 3, 246-251.

Katla, T., Moretro, T., Aasen, I.M., Holck, A., Axelsson, L., Naterstad, K., 2001. Inhibition of Listeria monocytogenes in cold smoked salmon by addition of sakacin P and/or live Lactobacillus sakei cultures. Food Microbiology 18, 431-439.

Kleerebezem, M., 2004. Quorum sensing control of lantibiotic production; Nisin and subtilin autoregulate their own biosynthesis. Peptides 25, 1405-1414.

Larsen, A.G., Vogensen, F.K., Josephsen, J., 1993. Antimicrobial activity of lactic acid bacteria isolated from sour dogs: purification and characterization of bavaricin A, a bacteriocin produced by Lactobacillus bavaricus MI401. Journal of Applied Bacteriology 75, 113-122.

Leroy, F., Foulquié Moreno, M.R., De Vuyst, L., 2003. Enterococcus faecium RZS C5, an interesting bacteriocin producer to be used as a co-culture in food fermentation. International Journal of Food Microbiology 88, 235-240.

Lindgren, S.W., Dobrogosz, W.J., 1990. Antagonistic activities of lactic acid bacteria in food and feed fermentations. FEMS Microbiology Reviews 87, 149-164.

Luchansky, J.B., Glass, K.A., Harsono, K.D., Degnan, A.J., Faith, N.G., Cauvin, B., Baccus-Taylor, G., Arihara, K., Bater, B., Maurer, A.J., Cassen, R.G., 1992. Genomic analysis of Pediococcus acidilactici in turkey summer sausage. Applied and Environmental Microbiology 58, 3053-3059.

Manca de Nadra, M.C., Sandino de Lamelas, D., Strasser de Saad, A.M., 1998. Pediocin N5p from Pediococcus pentosaceus: adsorption on bacterial strains. International Journal of Food Microbiology 39 (1-2), 79-85.

Mataragas, M., Drosinos, E.H., Metaxopoulos, J., 2003. Antagonistic activity of lactic acid bacteria against Listeria monocytogenes in sliced cooked cured pork shoulder stored under vacuum or modified atmosphere at $4 \pm 2{ }^{\circ} \mathrm{C}$. Food Microbiology 20, 259-265.

Mathieu, F., Michel, M., Lebrihi, A., Lefebvre, G., 1994. Effect of bacteriocin carnocin $\mathrm{CP} 5$ and of the producing strain Carnobacterium piscicola $\mathrm{CP} 5$ on the viability of Listeria monocytogenes in salt solution, broth and skimmed milk, at various incubation temperatures. International Journal of Food Microbiology $22,155-172$.

Ming, X., Daeschel, M.A., 1993. Nisin resistance of food borne bacteria and the specific resistance response of Listeria monocytogenes Scott A. Journal of Food Protection 56, 444-448.

Moll, G.N., Konings, W.N., Driessen, A.J.M., 1999. Bacteriocins: mechanism of membrane insertion and pore formation. Antonie Van Leeuwenhoek Journal of Microbiology 76, 185-198.

Nilsson, L., Gram, L., Huss, H.H., 1999. Growth control of Listeria monocytogenes on cold-smoked salmon using a competitive lactic acid bacteria flora. Journal of Food Protection 62, 336-342.

Nilsson, L., Ng, Y.Y., Christiansen, J.N., Jorgensen, B.L., Grotinum, D., Gram, L., 2004. The contribution of bacteriocin to the inhibition of Listeria monocytogenes by Carnobacterium piscicola strains in cold-smoked salmon system. Journal of Applied Microbiology 96, 133-143.
Núñez, M., Rodríguez, J.L., García, E., Gaya, P., Medina, M., 1997. Inhibition of Listeria monocytogenes by enterocins 4 during the manufacture and ripening of Manchego cheese. Journal of Applied Microbiology 83, 671-677.

Piva, A., Headon, D.R., 1994. Pediocin A, a bacteriocin produced by Pediococcus pentosaceus FBB61. Microbiology 140, 697-702.

Pucci, M.J., Vedamuthu, E.R., Kunka, B.S., Vandenbergh, P.A., 1988. Inhibition of Listeria monocytogenes by using bacteriocin PA-1, produced by Pediococcus acidilactici PAC 1.0. Applied and Environmental Microbiology 54, 2349-2353.

Rodgers, S., 2001. Preserving non-fermented refrigerated foods with microbial cultures - a review. Trends in Food Science and.Technology 12, 276-284.

Rodriguez, J.M., Martínez, M.I., Kok, J., 2002. Pediocin PA-1, a wide-spectrum bacteriocin from lactic acid bacteria. Critical Reviews in Food Science and Nutrition 42 (2), 91-121.

Sabia, C., Manicardi, G., Messi, P., de Niederhäusern, S., Bondi, M., 2002. Enterocin 416K1, an antilisterial bacteriocin produced by Enterococcus casseliflavus IM 16K1 isolated from Italian sausages. International Journal of Food Microbiology 75, 163-170.

Schillinger, U., Kaya, M., Lucke, F.K., 1991. Behavior of Listeria monocytogenes in meat and its control by a bacteriocin-producing strain of Lactobacillus sake. Journal of Applied Bacteriology 73, 309-316.

Schved, F., Lalazer, A., Henis, Y., Juven, B.J., 1993. Purification, partial characterization and plasmid linkage of pediocin $\mathrm{SJ}-1$, a bacteriocin produced by Pediococcus acidilactici. Journal of Applied Bacteriology 74, 67-77.

Stiles, M., 1996. Biopreservation by lactic acid bacteria. Antonie Van Leeuwenhoek Journal of Microbiology 70, 331-345.

Tichaczek, P.S., Nissen-Meyer, J., Nes, I.F., Vogel, R.F., 1992. Characterization of the bacteriocins Curvacin A from Lactobacillus curvatus LTH1174 and Sakacin P from L. sake LTH673. Systematic and Applied Microbiology 15, 460-468.

Tomé, E., Pereira, V.L., Lopes, C.I, Gibbs, P.A., Teixeira, T.C., 2007. In vitro tests of suitability of bacteriocin-producing lactic acid bacteria, as potential biopreservation cultures in vacuum-packaged cold-smoked salmon. Food Control. 19 (5), 535-543.

Tomé, E., Matsunaga, Y., Kodaira, M., 1999. Effect of processing conditions, lipids content and the freshness on acceptability of smoked catfish. Food Science and Technology International 5 (2), 167-175.

Työppönen, S., Petaja, E., Mattila-Sandholm, T., 2003. Bioprotectives and probiotics for dry sausages. International Journal of Food Microbiology 83, 233-244.

Vaz-Velho, M., Fonseca, F., Silva, M., Gibbs, P., 2001. Is Listeria innocua 2030c, a tetracycline resistant strain, a suitable indicator for replacing $L$. monocytogenes in challenge studies with cold-smoked fish? Food Control 12, 361-364.

Vaz-Velho, M., Todorov, S., Ribeiro, J., Gibbs, P., 2005. Growth control of Listeria innосиа 2030c during processing and storage of cold-smoked salmon-trout by Carnobacterium divergens V41 culture and supernatant. Food Control 16, 541-549.

Vescovo, M., Scolari, G., Zacconi, C., 2006. Inhibition of Listeria innocua growth by antimicrobial-producing lactic acid cultures in vacuum-packed cold-smoked salmon. Food Microbiology 23, 689-693.

Vogel, B.F., Ng, Y.Y., Hyldig, G., Mohr, M., Gram, L., 2006. Potassium lactate combined with sodium diacetate can inhibit growth of Listeria monocytogenes in vacuum-packed cold-smoked salmon and has no adverse sensory effects. Journal of Food Protection 69, 2134-2142.

Yoon, K.S., Burnette, C.N., Abou-Zeid, K.A., Whiting, R.C., 2004. Control of growth and survival of Listeria monocytogenes on smoked salmon by combined potassium lactate and sodium diacetate and freezing stress during refrigeration and frozen storage. Journal of Food Protection 67, 2465-2471.

Wan, J., Harmark, K., Davidson, B.E., Hillier, A.J., Gordon, J.B., Wilcock, A., Hickey, M.W., Coventry, M.J., 1997. Inhibition of Listeria monocytogenes by piscicolin 126 in milk and Camembert cheese manufactured with a thermophilic starter. Journal of Applied Microbiology 82, 273-280.

Wu, C.W., Yin, L.J., Jiang, S.T., 2004. Purification and characterization of bacteriocin from Pediococcus pentosaceus ACCEL. Food Chemistry 52 (5), $1146-1151$.

Yamazaki, K., Inoue, N., Montville, T.J., Suzuki, M., Kawai, Y., 2003. Inhibition of Listeria monocytogenes in cold-smoked salmon by Carnobacterium piscicola CS526 isolated from frozen surimi. Journal of Food Protection 66 (8), $1420-1425$. 